\title{
ACRL Legislative Network Backs Title II-A
}

On May 3 the ACRL Committee on Legislation and the ALA Washington Office sent out a call for action to the ACRL Legislative Network concerning funding of the Higher Education Act (HEA) Title I1-A College Library Resources Program. Developed gradually over the past several years, the ACRL Legislative Network consists of more than 200 college library directors across the country whose institutions have received II-A basic grants and who are committed to contacting their members of Congress when appropriate and necessary. An updated version of the May 3 memorandum to the ACRL Legislative Network made the following points.

\section{Carter Budeet. FY 1980}

In the administration's "lean and austere" budget submitted to Congress in January, college library and library training and demonstration programs would not be funded at all. The only library program in relatively good shape is the HEA Title II-C research library program, recommended for funding at last year's level of $\$ 6$ million.

\section{College Library Resol'rCes-HEA II-A}

Once funded at $\$ 25,000,000$ in the late 1960 s, the HEA II-A funding level is now only $\$ 9,975,000$ in FY 1979 , and its purchasing power has been sharply eroded. Although the amount of the basic grant has dwindled to $\$ 3,963$, it still represents a substantial percentage of the materials budget of many an academic library.

The ALA request, presented in the Senate on March 28 and in the House on April 26, is $\$ 21$ million. About $\$ 13$ million is needed to fund the basic grants for library resources at the full $\$ 5,000$ based on the number of eligible institutions applying in recent years.

\section{Tue Situation in Congress}

This is not the year to sit back and assume that the Office of Management and Budget in the executive branch is playing the game of making cuts in those areas where Congress is most likely to restore funds. Both House and Senate are in the process of setting congressional budget targets below the president s budget-an action that would set strict limits on Congress' ability to raise funding levels for any program. Furthermore, budget cuts will fall most heavily on the "controllable" items in the budget. And the most vulnerable of the "controllable" items are smaller programs, like library programs, that lack large, well-organized, and influential constituencies.

\section{LJBRARY SUPPORTERS IN CONGRESS}

The message from library supporters in Congress is to get out there and defend your pro- grams, and don't let anyone tell you that the amounts you are requesting will "bust the budget." Congressman John Buchanan (R-Ala.), ranking minority member of the House Postsecondary Education Subcommittee, said that one of the worst things the Office of Management and Budget has done is to cut the good, small programs severely without realizing real budgetary savings. When told how many college libraries there are in the United States, Congressman Bill Ford (D-Mich.) said that if each one of them contacted its representatives about funding for the college library program, it would "boggle their minds."

\section{How You Can Help}

The May 3 memorandum asked ACRL Legislative Network members to contact their legislators to urge the restoration of funds for Title II-A at the level of $\$ 21$ million for FY 1980. The memo also suggested that members urge their library colleagues and interested faculty, students, and administrators to do the same. Many members of the network responded immediately.

As we update this memorandum in mid-May, it is not yet clear what action the House and Senate Labor-HEW Appropriations Subcommittees or Congress as a whole will take on HEA II-A funding. By the time you read this in July, the House and Senate will probably have acted separately on the Labor-HEW appropriations bill that contains HEA II-A funding. The most likely timetable for early July is that the House-Senate conference committee will be about to meet. If one chamber has a higher figure for II-A than the other, it will be important to write to conference committee members supporting the higher figure. College librarians are urged to check the most recent issue of the ALA Washington Newsletter for details. - Carol Henderson \& David Bishop.

\section{BISHOP TESTIFIES ON RESULTS OF TITLE II-A SURVEY}

College Library Resources Program grants have played a useful, sometimes vital, role in assisting the nation's academic libraries, David Bishop, chair of the ACRL Legislation Committee, told a House subcommittee on April 26.

The College Library Program, authorized under Title II-A of the Higher Education Act, this year provided basic grants averaging about $\$ 3,900$ each to nearly every college and university library in the country. Legislative authorization for all Title II programs will expire in September 1979. 
Bishop, new director of the University of Georgia Libraries, Athens, told the House Subcommittee on Postsecondary Education that support for the program was particularly strong among medium-sized and smaller institutions with library book budgets under $\$ 150,000$.

Bishop based his testimony on the results of a survey sent to more than 500 library directors randomly selected from the Title II-A recipient list. The survey was prepared by the ACRL Legislative Committee and the ALA Washington Office.

Directors of libraries with book budgets under $\$ 150,000$ accounted for three-quarters of the respondents to the survey. Forty-four percent of these directors reported that they wanted to see the College Library Resources Program continued unchanged. Fifty-two percent indicated that they wanted the program amended, but the change that 75 percent of them wanted was to base the program on need. Only a small fraction of responding directors from medium-sized and smaller libraries wanted to repeal the program or alter it in a major way.

Among the directors of university libraries with book budgets of more than $\$ 150,000,31$ percent of the respondents wanted the program to continue unchanged; 62 percent wanted it amended. Forty-one percent of those who wanted amendments favored basing the grants on need.

"It is clear," Bishop told the subcommittee, "that the program needs to be focused better than it is at present. An overwhelming majority want the program based on need, but 'need' should be defined so that it includes the bulk of the country's junior and four-year colleges."

Bishop stressed the point that for the smaller institutions the grants are not marginal. He quoted the following comment of a librarian at a private two-year college in Georgia on the effect that ending the program would have on his institution: "We would be reduced," he said, "almost to the 'starvation level' of buying, as the grant is two-fifths of our entire materials budget."

A librarian from a public two-year college in California cited another benefit of the program: "The maintenance-of-effort requirement associated with II-A has definitely helped to keep our budget up. Our college administration has maintained our budget.... , and the II-A grant has provided support for maintaining the levels."

The end of the program, Bishop told the subcommittee, would mean a collective as well as an individual loss to the nation's libraries. Title II-A funds made possible the purchase of approximately 500,000 volumes last year. These volumes create a common pool of scholarly materials upon which college libraries can draw through interlibrary loans.

In conclusion, Bishop recommended that Congress reauthorize the College Library Resources Program essentially in its present form but with a provision excluding institutions above a certain size. He asked that funding levels for basic grants be increased to $\$ 10,000$ and supplemental grants be continued for the neediest institutions.

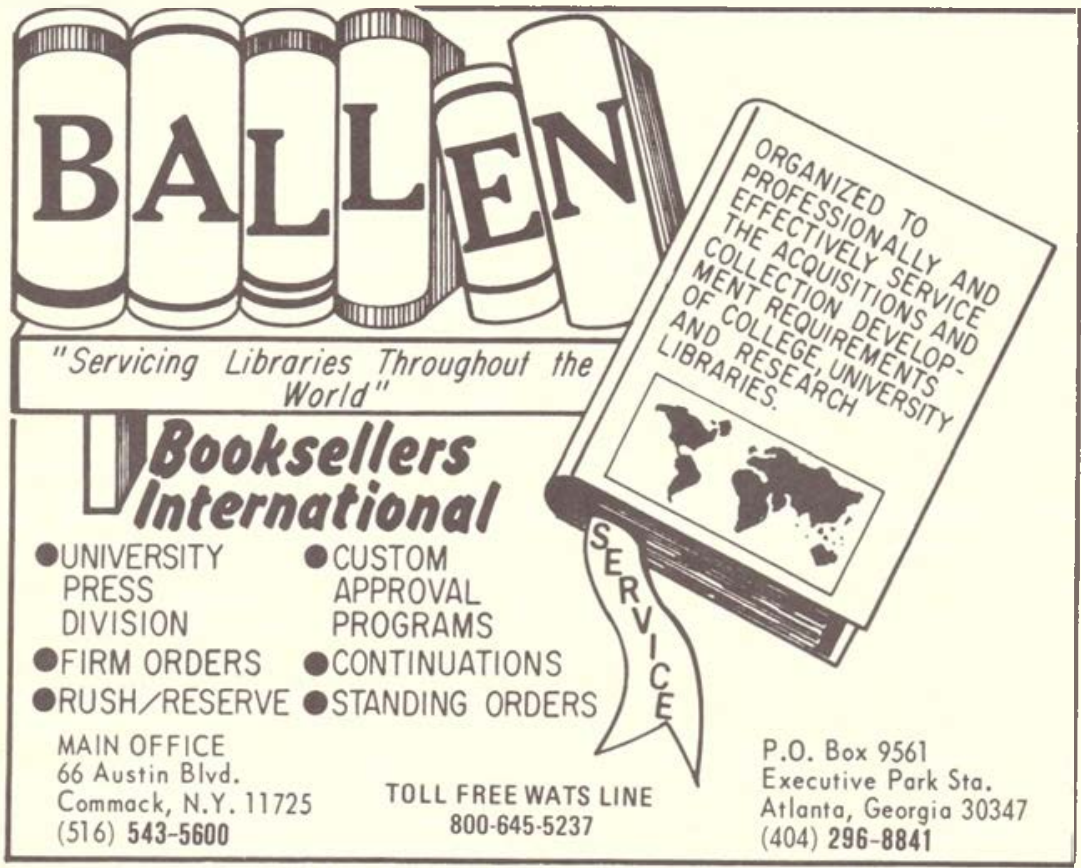

